\title{
TIME REDUCTION FOR SURINAM GRASS SEED GERMINATION TEST
}

\author{
Redução do tempo para o teste de germinação de sementes de capim-braquiária
}

\author{
Camila de Aquino Tomaz ${ }^{1}$, Cibele Chalita Martins', \\ Mauricio Feis Ganz Sanches ${ }^{3}$, Roberval Daiton Vieira ${ }^{3}$
}

\begin{abstract}
The period for the germination test of Surinam grass seeds established by the Rules for Seeds Testing is 28 days, considered too lengthy by producers, venders, and seed analysis laboratories. So, the objective of this research was to evaluate the possibility of reducing the time for the germination test of Surinam grass seeds and to establish a method for dormancy breaking and the ideal temperature. Ten seed lots were submitted to the following treatments to overcome seed dormancy: control; substrate moistening with $0.2 \% \mathrm{KNO}_{3}$; and scarification with sulfuric acid $(98 \% 36 \mathrm{~N})$ for 15 minutes. After the treatments, the lots were submitted to seed water content, germination and tetrazolium tests. During the germination test, conducted with four replicates of 100 seeds per treatment for 28 days, two conditions of alternating temperatures $\left(20-35^{\circ} \mathrm{C}\right.$ and $\left.15-35^{\circ} \mathrm{C}\right)$ with 8 hours of light were tested. Attempting to determine the test end date, daily counts of the number of normal seedlings were made and for each lot, treatment, and temperature, a growth curve for the evaluation of germination was adjusted. The segmented regression model parameter estimations were calculated for each treatment. The germination test of Braquiaria decumbens seeds may be evaluated in 12 days after sowing using alternating temperatures of $20-35^{\circ} \mathrm{C}$ and without any treatment to overcome dormancy.
\end{abstract}

Index terms: Brachiaria decumbens; dormancy overcoming; ideal temperature.

\section{RESUMO}

O tempo para o teste de germinação de sementes de capim-braquiária estabelecidos pelas Regras de Análise de Sementes é de 28 dias, sendo considerado muito longo por produtores, vendedores e laboratórios de análise de sementes. Portanto, o objetivo desta pesquisa foi avaliar a possibilidade de reduzir o tempo para o teste de germinação de sementes de capim-braquiária, estabelecendo o método de quebra de dormência e a temperatura ideal. Dez lotes de sementes foram submetidos aos seguintes tratamentos para quebra de dormência: controle; umedecimento do substrato com solução de $0,2 \%$ de $\mathrm{KNO}_{3}$; e escarificação com ácido sulfúrico $(98 \% 36 \mathrm{~N})$ por 15 minutos. Após os tratamentos, os lotes foram submetidos à determinação do teor de água e aos testes de germinação e de tetrazólio. Durante o teste de germinação, realizado com quatro repetições de 100 sementes por tratamento por 28 dias, foram testadas duas condições de temperaturas alternadas $\left(20-35^{\circ} \mathrm{C}\right.$ e $\left.15-35^{\circ} \mathrm{C}\right)$, com 8 horas de luz. Visando determinar a data de término do teste foram feitas as contagens diárias do número de plântulas normais e, foi ajustada uma curva de crescimento para a avaliação da germinaçãopara cada lote, tratamento e temperatura. O teste de germinação de sementes de Braquiária decumbens pode ser avaliado em 12 dias após a semeadura utilizando-se temperaturas alternadas de 20-35 ${ }^{\circ} \mathrm{C}$, sem qualquer tratamento de quebra de dormência.

Termos para indexação: Brachiaria decumbens; superação de dormência; temperatura ideal.

\section{INTRODUCTION}

Brazil is the largest world producer and exporter of tropical forage seeds with a total production of approximately 100 thousand tons of pure viable seeds. Brachiaria decumbens Stapf. seeds occupy the second position in this market; it is surpassed only by Brachiaria brizantha (Hochst. ex A. Rich) Stapf. Around $20 \%$ of the total amount of produced forage tropical seeds is exported to at least 16 countries predominantly from South and
Central America, Africa, and the United States of America. The size of that market is estimated as being around US\$ 600 million dollars a year (Verszignassi, 2013). The seed industry plays a vital role in pasture implantation and restoration in modern integration systems by providing the necessary seeds of high quality and in the needed amounts. In the quality control program of a seed company, evaluating seed germination is of fundamental importance for a successful production program. The germination test is standardized and it follows specific temperature,

\footnotetext{
${ }^{1}$ Universidade Estadual Paulista/UNESP - Faculdade de Ciências Agronômicas - Campus de Botucatu - Fazenda Experimental Lageado - Botucatu $\mathrm{SP}-$ Brasil

${ }^{2}$ Universidade Estadual Paulista/UNESP - Faculdade de Ciências Agrárias e Veterinárias - Campus de Jaboticabal - $14884-900$ - Jaboticabal - SP _ Brasil - cibele@fcav.unesp.br

${ }^{3}$ Universidade Estadual Paulista/UNESP - Faculdade de Ciências Agrárias e Veterinárias - Campus de Jaboticabal - Jaboticabal - SP - Brasil

Received in february 11, 2015 and approved in july 20, 2015
}

Ciênc. Agrotec., Lavras, v. 39, n. 5, p. 488-497, set./out., 2015 
light, moistening, substrate type, dormancy overcoming methods, dates, and germination evaluation methods. This standardization of conditions is the basis for making comparisons between results of different seed lots and laboratory analysis (Tomaz et al., 2010).

The recommended duration of the germination test of seeds of the genus Brachiaria is of 21 days with the possibility of being extended to 28 days when dormant seeds are found to occur (Brasil, 2009; International Seed Testing Association -ISTA, 2009). This is considered a long period by seed analysis laboratories, seed companies, and farmers who produce and sell those seeds, considered as a barrier for the choosing and buying of seed lots. So, the seed lots bought by a farmer are chosen with basis more on his experience and intuition (Dias; Alves, 2008) and on the results of the purity and tetrazolium tests, according to the Normative Instruction number 30 (Brasil, 2008).

The current recommendations for the germination test of $B$. decumbens seeds are similar to those published in the 1990s, when the technology for forage seed production in Brazil was less evolved and the financial investments in that area were far lower than those invested in the present time (Maschietto; Novembre; Silva, 2003). Most of the seed produced at that time were handpicked from the spike or mechanically harvested with a cereal harvester and thus the seeds had larger proportions of dormant, immature seeds, which were consequently less vigorous and showed lower germination values (Zanuzo; Muller; Miranda, 2010).

Low vigor and dormancy are factors causing irregularity and tardiness in germination test results (Maschietto; Novembre; Silva, 2003). In the present time, most of the Surinam grass in Brazil is harvested after physiological maturity, when seeds fall to the ground and then are collected by sweeping the soil surface. After this process, they are either collected by workers or by a machine specially developed for this purpose. The seeds harvested this way usually have high physiological quality (Quadros et al., 2012).

Researches carried out during the last decade showed that the grasses $B$. brizantha and Panicum maximum Jacq. could have their germination test period reduced by half or less than half (Gaspar-Oliveira et al., 2008; Tomaz et al., 2010). This fact could also occur with Surinam seeds, but research data with this species are still lacking.

Besides the duration of the germination test, choosing the temperature and method to overcome seed dormancy among those recommended by the Rules for Seed Testing (Brasil, 2009) may give origin to doubts during the germination test since these options may influence the results, hampering germination. For seeds of $B$. decumbens there are two ranges of alternating temperatures which are considered optimal and are recommended, that is $20-35^{\circ} \mathrm{C}$ and $15-35^{\circ} \mathrm{C}$.

The use of alternating temperatures in germination tests is an attempt to simulate the conditions that occur naturally and usually favors the germination of the seeds of several species, once they cause the suppression of seed dormancy, such as is the case of grass forage species (Carvalho; Nakagawa, 2012).

In addition to alternating temperatures and the use of light as conditions for the germination test of grass seeds, the use of specific treatments for overcoming seed dormancy, such as the immersion of the seeds in concentrated sulfuric acid for 15 minutes and/or a $0.2 \%$ solution of potassium nitrate is also recommended. Moistening the substratum with potassium nitrate may lead to increased or, in some cases, to decreased total and speed of germination, this last case being the one verified when the seeds have no degree of dormancy (Dias; Alves, 2001; Gaspar-Oliveira et al., 2008; Tomaz et al., 2010).

Based on what was exposed, it is essential to reduce the duration of Surinam grass seed germination and to determine the best conditions of temperature and treatment for breaking dormancy, attempting to increase the germination and facilitate the use of this methodology.

So, the objective of this research was to verify the possibility of reducing the period of time necessary for the germination test of $B$. decumbens seeds and thus establish the method to overcome seed dormancy and the ideal temperature.

\section{MATERIAL AND METHODS}

Ten commercial B. decumbens seed lots of several points of origin in the Brazilian states of Bahia, Minas Gerais, and São Paulo were used in this research. All of them were, upon reception by the seed company, sampled, homogenized, submitted to cleaning by means of screens and of a pneumatic blower and further processed by manual separation to obtain pure seeds. These seeds were submitted to treatments to overcome seed dormancy: 1) control; 2) $0.2 \% \mathrm{KNO}_{3}$ solution moistening the substratum; and 3) scarification with sulfuric acid $(98 \% 36 \mathrm{~N})$ for fifteen minutes followed by a washing in tap water and drying in the shade.

After the treatments, seed water content and germination test were conducted according to Brasil (2009) and ISTA (2009), and tetrazolium test was executed according to Novembre, Chamma, and Gomes (2006), as described below: 
Seed water content: Two subsamples of $2.0 \mathrm{~g}$ seeds each were submitted to a temperature of $105 \pm 3{ }^{\circ} \mathrm{C}$ for 24 hours in a ventilated oven. Seed water content was also determined after the seeds were treated with sulfuric acid to break dormancy following the procedure previously described.

Germination test: Four subsamples of 100 seeds each were placed inside transparent plastic boxes measuring $(11 \times 11 \times 3.5 \mathrm{~cm})$ and on top of two filter papers which had been previously moistened with an amount of deionized water corresponding to twice the paper weight or with $0.2 \% \mathrm{KNO}_{3}$, when this treatment was applied. The seeds were kept under two alternating temperature conditions: 1) $15-35^{\circ} \mathrm{C}$ for $16-8$ hours under light; and 2) $20-35^{\circ} \mathrm{C}$ for $16-8$ hours under light. Seedling counts were made daily up to 21 days after sowing (speed of germination index) and another seven day additional period, thus totalizing 28 days, considering normal emerged seedlings with plumule and primary root with at least $0.5 \mathrm{~cm}$ long. The date to end the test was also established during this test.

Tetrazolium test: Remaining seeds from the germination test were longitudinally and medially sectioned through the embryo and one of the halves of each seed was immersed in a $0.075 \%$ tetrazolium solution and kept in a dark chamber at $40{ }^{\circ} \mathrm{C}$ for a period of two hours. After that period, the seeds were washed and the evaluation made immediately after and the seeds were classified as either viable or non-viable (dead).

The treatments were arranged according to a factorial scheme $(3 \times 2)$ in which the first factor was the treatments for breaking seed dormancy and the second the temperatures. The statistical design was that of a randomized complete block in which the blocks were the commercial seed lots.

For each lot (block), a growth curve was adjusted using the nonlinear model to evaluate the percentage of germination. By means of the non linear model, the time necessary for the duration of the test was determined. This value was calculated based on the lack of significant difference between the asymptote and the estimated function (Gaspar-Oliveira et al., 2008).

Curves were adjusted with the model: $\mathrm{y}=\mathrm{a} /(1+\exp (-$ $\mathrm{b}+\mathrm{c} * \mathrm{x})$ ); where " $\mathrm{a}$ " is the asymptote representing the percentage of germination, " $\mathrm{b}$ " is the position parameter representing the curve dislocation, "c" is related to the growth rate which represents the speed of germination, and " $\mathrm{X}$ " represents the test duration. The used regression model was of the type: $Y_{i}=L+U\left(R-X_{L R i}\right)+e_{i}, i=1,2 \ldots n_{i}, n_{i+1}, \ldots$, $n$; whose $R-X_{L R i}=0$ for $i \geq n_{1}+1$, and " $n_{1}$ " is the number of observations till the stabilization point, and " $n$ " is the number of observation pairs. Where Y represents the percentage of germination, L represents the point of maximum germination, $\mathrm{U}$ represents the determination coefficient, $\mathrm{R}$ represents the stabilization date, $X_{\mathrm{LRi}}$ represents the duration (days), and " $\mathrm{e}_{\mathrm{i}}$ " is the random component, or residue.

The analysis of variance by the F test $(p>0.05)$ was made for each parameter of the function $(a, b, c)$ and those parameters were replaced in the equation for the calculation of " $x$ ". The means of the parameters were compared by the Tukey test $(\mathrm{p}>0.05)$.

\section{RESULTS AND DISCUSSION}

The seed lots presented seed water content before and after seed scarification with sulfuric acid around 7.3 and $12.0 \%$, respectively (data not shown). Scarifying the seeds with sulfuric acid removes their protective covers thus making easier water entry in the seeds which anticipates germination (Marousky; West, 1988). Since after scarification, the seeds were washed in running water and then placed on paper towel, the approximate period of two hours during which they remained wet was enough to cause the seeds to absorb water in a way similar to that reported by Gaspar-Oliveira et al. (2008) with seeds of $B$. brizantha cv. Marandu.

Seed initial water content is a primordial factor for the standardization of procedures to be carried out afterwards. It is recommended that the seed samples to be compared do not show moisture content differences which may compromise the results due to the influence the initial moisture content has on seed speed of water absorption (Marcos Filho, 1999). The difference in seed water content before and after scarification was of 4.7 percentage points and this difference was not enough to change seed speed of germination, as shown in Figure 1.

The $B$. decumbens observed germination percentage values are close to the estimated ones, this being an indication that the data adjustment was of the logistic regression model $\mathrm{y}=\mathrm{a} /(1+\exp (-\mathrm{b}+\mathrm{c} * \mathrm{x}))$ (Figure 1).

Seed germination percentage, in all dormancy breaking treatments, was superior to $60 \%$, this being an acceptable value for the marketing of the seeds of categories S1 and S2, according to the Normative Instruction N. 30 of May 23, 2008 (Brasil, 2008).

The only parameter significantly affected by the interaction between dormancy breaking treatments and temperatures was the seed percentage of germination (a) (Table 1), and have not been verified effects of isolated factors (dormancy breaking treatment or temperature). 


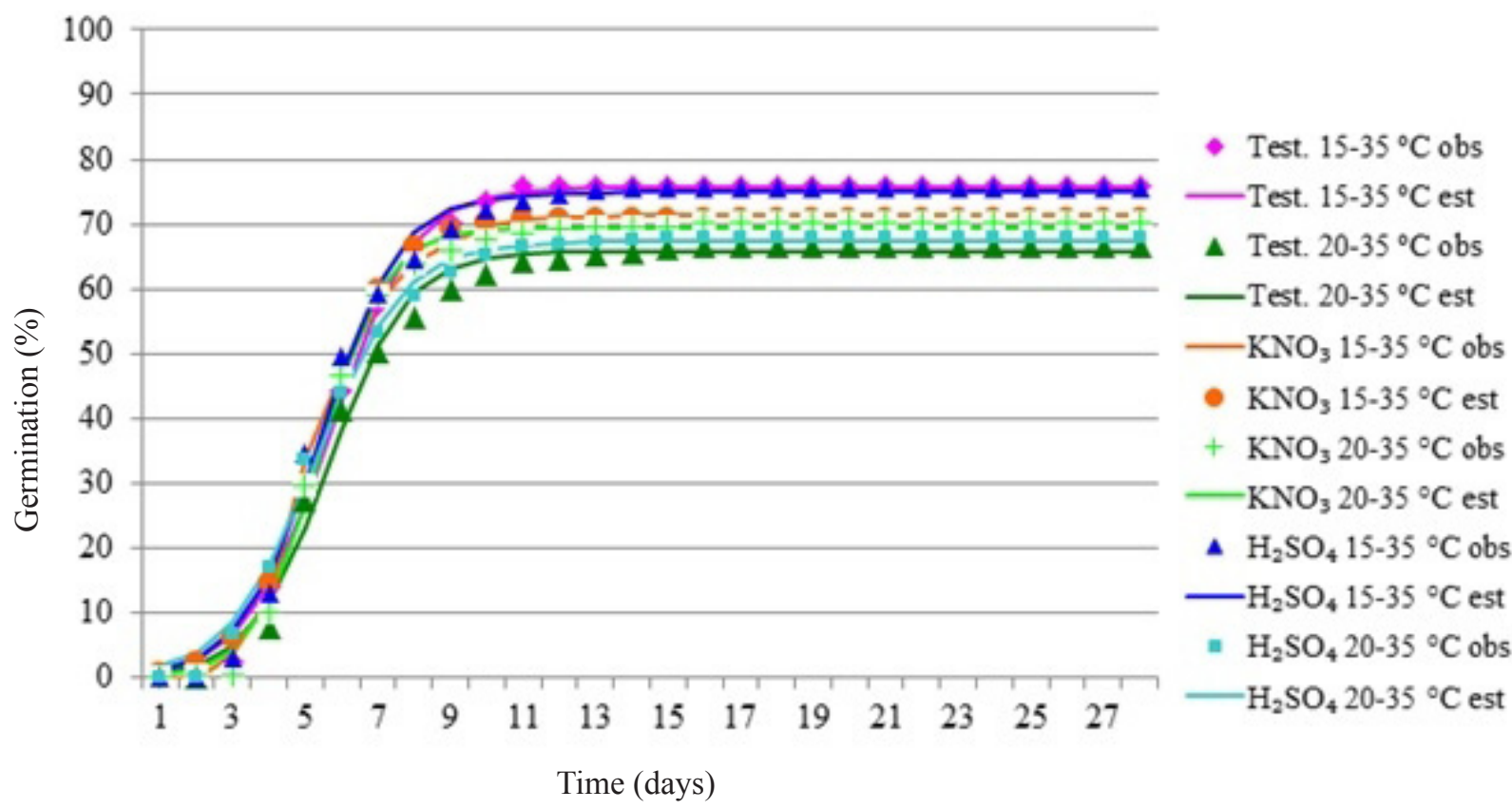

Figure 1: Estimated (est) (logistic model:y=a/(1+exp $\left(-\left(b+c^{*} x\right)\right)$ and observed (obs) germination percentage values of B. decumbens seeds as a function of time.

Table 1: $\mathrm{F}$ values and significance of the estimations of parameters referring to germination percentage (a), germination stabilization date (b), and seed speed of germination (c) of B. decumbens seeds.

\begin{tabular}{lccc}
\hline \multicolumn{1}{c}{ Sources of variation } & $\begin{array}{c}\text { Germination } \\
\text { percentage (a) }\end{array}$ & $\begin{array}{c}\text { Germination } \\
\text { stabilization date (b) }\end{array}$ & $\begin{array}{c}\text { Seed speed } \\
\text { of germination (c) }\end{array}$ \\
\hline Dormancy breaking treatment & $1.86^{\mathrm{ns}}$ & $0.28^{\mathrm{ns}}$ & $0.16^{\mathrm{ns}}$ \\
Temperature & $3.77^{\mathrm{ns}}$ & $0.28^{\mathrm{ns}}$ & $0.23^{\mathrm{ns}}$ \\
Dormancy breaking treatment $\times$ Temperature & $3.16^{*}$ & $0.78^{\mathrm{ns}}$ & $0.40^{\mathrm{ns}}$ \\
\hline
\end{tabular}

*, ns: significant at the level of $5 \%$ and non significant, according to the $\mathrm{F}$ test, respectively.

At the alternating temperatures of $20-35^{\circ} \mathrm{C}$ there was no difference between the treatments for overcoming dormancy and the check treatment as measured by the germination test (Table 2). So, treating the seeds either with sulfuric acid or with nitrate potassium may be dispensed with if the test is carried out at the alternating temperatures of $20-35{ }^{\circ} \mathrm{C}$ and this would mean that the test could be faster, easier, and less costly.

At the alternating temperatures of $15-35{ }^{\circ} \mathrm{C}$, the highest germination percentage (81.0) resulted when the $B$. decumbens seeds were exposed to the dormancy overcoming treatment with the $\mathrm{KNO}_{3}$ solution in comparison with the treatment with sulfuric acid and the check treatment (Figure 1 and Table 2). Toledo, Chamma and Novembre, (1995) verified that $\mathrm{H}_{2} \mathrm{SO}_{4}$ used to break P. maximum seeds dormancy was not effective when the germination test was run at the alternating temperatures of 15-35 ${ }^{\circ} \mathrm{C}$. Tomaz et al. (2010) reported that P. maximum cv. Tanzânia seeds exposed to a $\mathrm{KNO}_{3}$ solution imbibing the substratum germinated better than seeds exposed to sulfuric acid and the check treatment.

In the literature, papers are found which mention the positive effect of nitrate potassium solution on seed germination, mainly of grass species. This is supposed to be a dormancy breaking effect ascribed to the reaction between $\mathrm{KNO}_{3}$ and $\mathrm{O}_{2}$ fixing substances occurring in the seed pellicle-pericarp complex (Carvalho; Nakagawa, 2012). 
Dormancy breaking treatments and temperatures did not lead to significantly different dates of germination stabilization; this date took place approximately 12 days after the tests were sown (Table 3 ), this indicating that even when dormancy breaking treatments were not applied and the test run under anyone of the temperature regimens, the period for the final $B$. decumbens seedling evaluation could be reduced to half that indicated by the Rules for Testing Seeds (Brasil, 2009).

$B$. decumbens seed speed of germination was not significantly affected by dormancy breaking treatments and alternating temperatures (Table 4). So, the higher water content shown by acid scarified seeds had no significant effect on seed speed of germination (Table 1). Usberti and Martins (2007) and Gaspar-Oliveira et al. (2008) reported a positive effect of acid scarification on $B$. brizantha seed speed of germination so that the effect of this treatment seems to be species-dependent.

The experimental conditions contributed for the fast germination of the $B$. decumbens seeds in comparison with those recommended by the Rules for Testing Seeds (Brasil, 2009; ISTA 2009) (Table 4). The effect of temperature on seed speed of germination is due to its affecting the speed of water absorption which is higher at high temperatures and lower at low temperatures (Carvalho; Nakagawa, 2012; Marcos Filho, 2005).

Table 2: Mean and standard deviation of the parameter estimation referring to the germination percentage of $B$. decumbens seeds as influenced by the treatments to overcome seed dormancy and temperature.

\begin{tabular}{cccc}
\hline \multirow{2}{*}{ Dormancy breaking treatment } & \multicolumn{2}{c}{ Temperature $\left({ }^{\circ} \mathrm{C}\right)$} & \multirow{2}{*}{ Means } \\
\cline { 2 - 3 } & \multicolumn{1}{c}{$15-35$} & $20-35$ & \\
\hline Control & $65.76 \pm 18.54 \mathrm{aB}$ & $77.10 \pm 10.51 \mathrm{aA}$ & $71.43 \pm 15.78$ \\
$\mathrm{KNO}_{3}$ & $81.04 \pm 10.11 \mathrm{aA}$ & $75.81 \pm 12.78 \mathrm{aA}$ & $78.43 \pm 11.53$ \\
$\mathrm{H}_{2} \mathrm{SO}_{4}$ & $65.73 \pm 16.15 \mathrm{aB}$ & $78.58 \pm 7.17 \mathrm{aA}$ & $72.16 \pm 13.83$ \\
\hline Means & $70.84 \pm 16.52$ & $77.17 \pm 10.11$ & \\
\hline
\end{tabular}

Means in the same line, followed by the same small case letter, and in the same column, followed by the same large case letter, are not statistically different at the level of $5 \%$ of probability according to Tukey test.

Table 3: Mean and standard deviation of the parameter estimation referring to the date for germination stabilization (days after sowing) of $B$. decumbens seeds as influenced by the treatments to overcome seed dormancy and temperatures.

\begin{tabular}{|c|c|c|c|}
\hline \multirow{2}{*}{ Dormancy breaking treatment } & \multicolumn{2}{|c|}{ Temperature $\left({ }^{\circ} \mathrm{C}\right)$} & \multirow{2}{*}{ Means } \\
\hline & $15-35$ & $20-35$ & \\
\hline Control & $6 \pm 6$ & $12 \pm 24$ & $9 \pm 17$ \\
\hline $\mathrm{KNO}_{3}$ & $8 \pm 2$ & $7 \pm 4$ & $7 \pm 3$ \\
\hline $\mathrm{H}_{2} \mathrm{SO}_{4}$ & $9 \pm 5$ & $8 \pm 3$ & $9 \pm 4$ \\
\hline Means & $8 \pm 5$ & $9 \pm 14$ & \\
\hline
\end{tabular}

Table 4: Mean and standard deviation of the parameter estimation referring to the speed of germination of $B$. decumbens seeds as influenced by the treatments to overcome seed dormancy and temperatures.

\begin{tabular}{cccc}
\hline \multirow{2}{*}{ Dormancy breaking treatment } & \multicolumn{2}{c}{ Temperature $\left({ }^{\circ} \mathrm{C}\right)$} & \multirow{2}{*}{ Means } \\
\cline { 2 - 3 } & $15-35$ & $20-35$ & $1.59 \pm 2.85$ \\
\hline Control & $1.22 \pm 1.01$ & $1.95 \pm 3.97$ & $1.30 \pm 0.48$ \\
$\mathrm{KNO}_{3}$ & $1.31 \pm 0.32$ & $1.29 \pm 0.62$ & $1.41 \pm 0.63$ \\
$\mathrm{H}_{2} \mathrm{SO}_{4}$ & $1.47 \pm 0.78$ & $1.36 \pm 0.48$ & \\
\hline Means & $1.33 \pm 0.74$ & $1.53 \pm 2.28$ &
\end{tabular}

Ciênc. Agrotec., Lavras, v. 39, n. 5, p. 488-497, set./out., 2015 
In Figures 2, 3, 4, 5, 6 and 7 the segmented regression model described by Portz, Dias and Cyrino (2000) is verified to occur - it is represented by two segments: an inclined ascending or descending line followed by a horizontal line whose intersection point will determine the stabilization point. This one inclination model is more adequate to estimate germination or growth parameters. Those figures show that the period of time of 21 days recommended for the standard germination test of B. decumbens seeds may be considered long since 12 days permitted the stabilization of germination independently of the application of dormancy breaking treatments and temperature conditions.

The fact that the stabilization of $B$. decumbens seed germination was reached at practically half the period of time indicated by the Rules for Testing Seeds is important from the economical point-of-view since it permits getting results more quickly thus improving the decision-making processes and reducing the germinators period of occupation. Similar results were reported by Gaspar-Oliveira et al. (2008) with B. brizantha seeds.
As a general observation, it was verified that $B$. decumbens seed speed of germination and date for final count of the germination test were not significantly influenced by the treatments for overcoming dormancy and the temperature regimens. The tetrazolium test carried out at the end of the germination test showed that the seeds that had not germinated were dead and not dormant. The fact that the used seed lots showed no dormancy is probably due to the time elapsed between the seeds physiological maturity moment and that of the beginning of the experiment, which was superior to 4 months, this being a period of time enough for the natural suppression of dormancy in seeds of the genus Brachiaria and Panicum (Souza, 2001; Martins; Silva, 1998). This period of time between the seeds falling to the ground and their picking, storing at farm level, sale and transport to the processing unit is most of the times around 4 months.

So, the treatments viewing dormancy suppression are more effective if applied to recently harvested seeds since just after seeds reach physiological maturity they exhibit deeper levels of dormancy such as was reported by Oliveira and Mastrocola (1983).

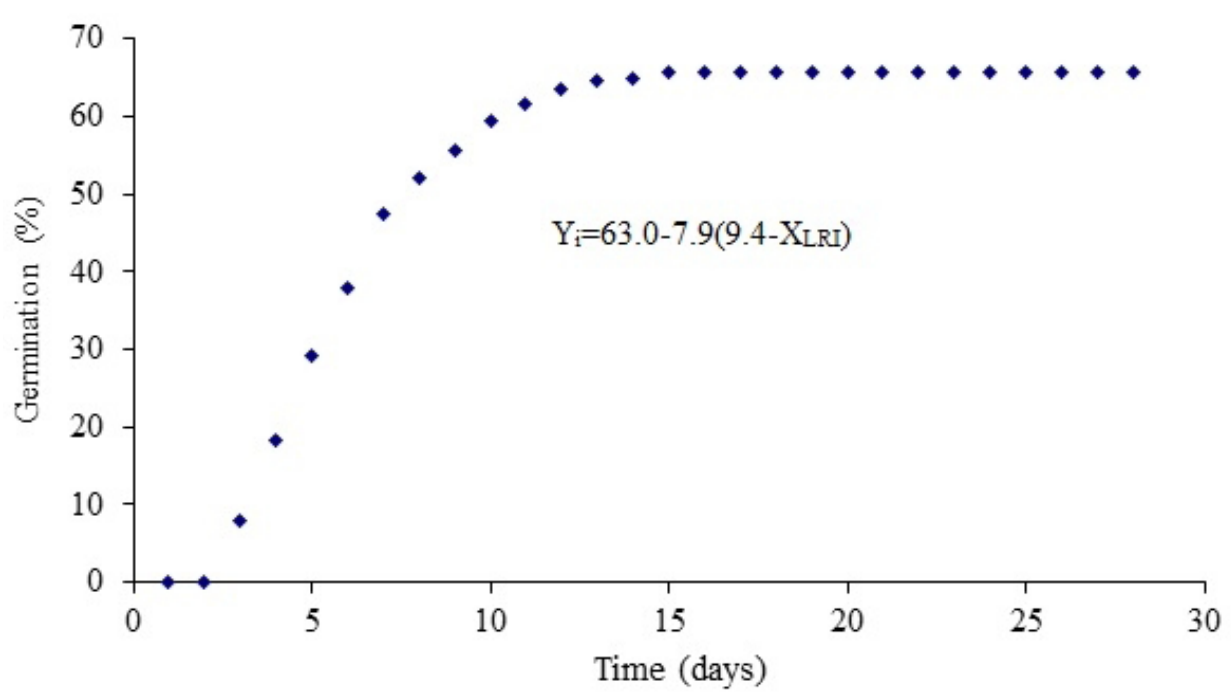

Figure 2: Germination percentage point of $B$. decumbens seeds germinating in a substrate moistened with water and at alternating temperatures of $15-35^{\circ} \mathrm{C}$. 


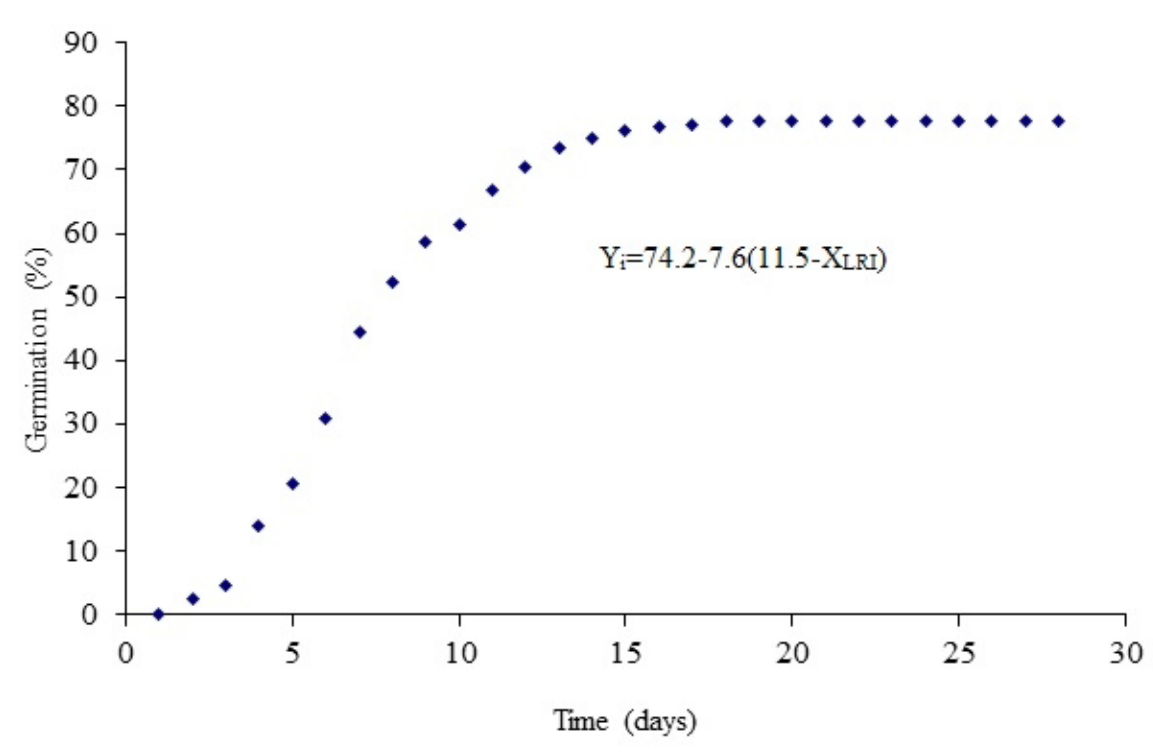

Figure 3: Germination percentage point of $B$. decumbens seeds germinating in a substrate moistened with water and at alternating temperatures of $20-35^{\circ} \mathrm{C}$.

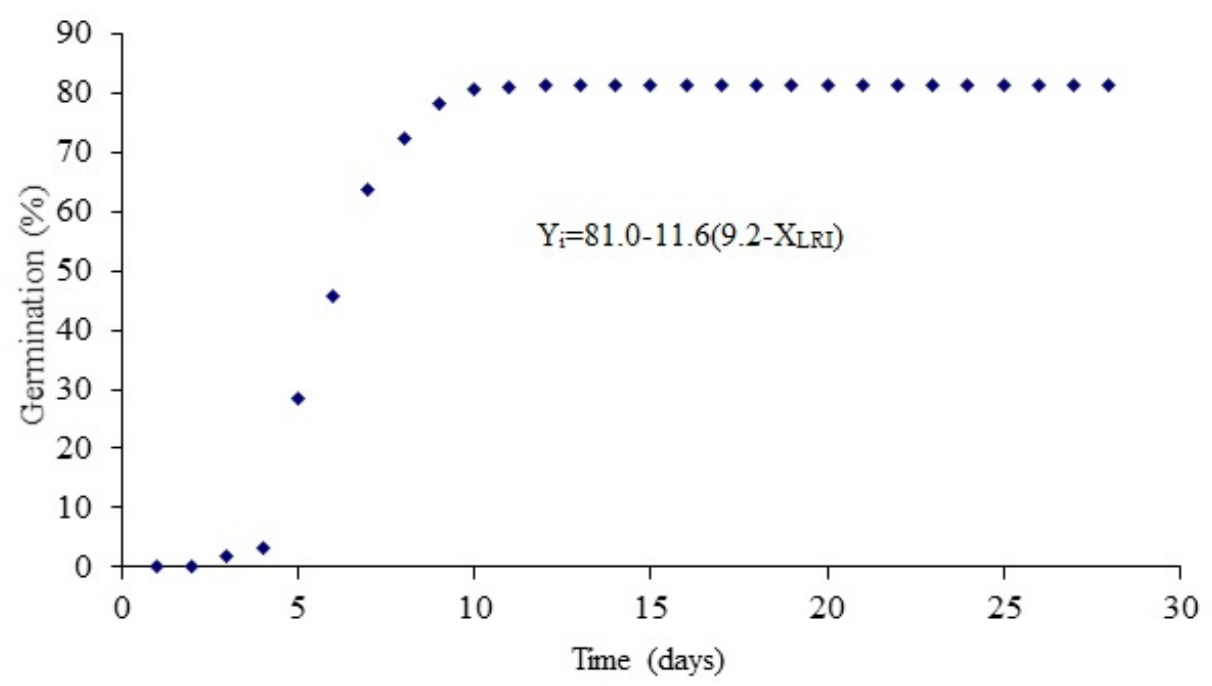

Figure 4: Germination percentage point of $B$. decumbens seeds germinating in a substrate moistened with a $\mathrm{KNO}_{3}$ solution and at alternating temperatures of $15-35^{\circ} \mathrm{C}$. 


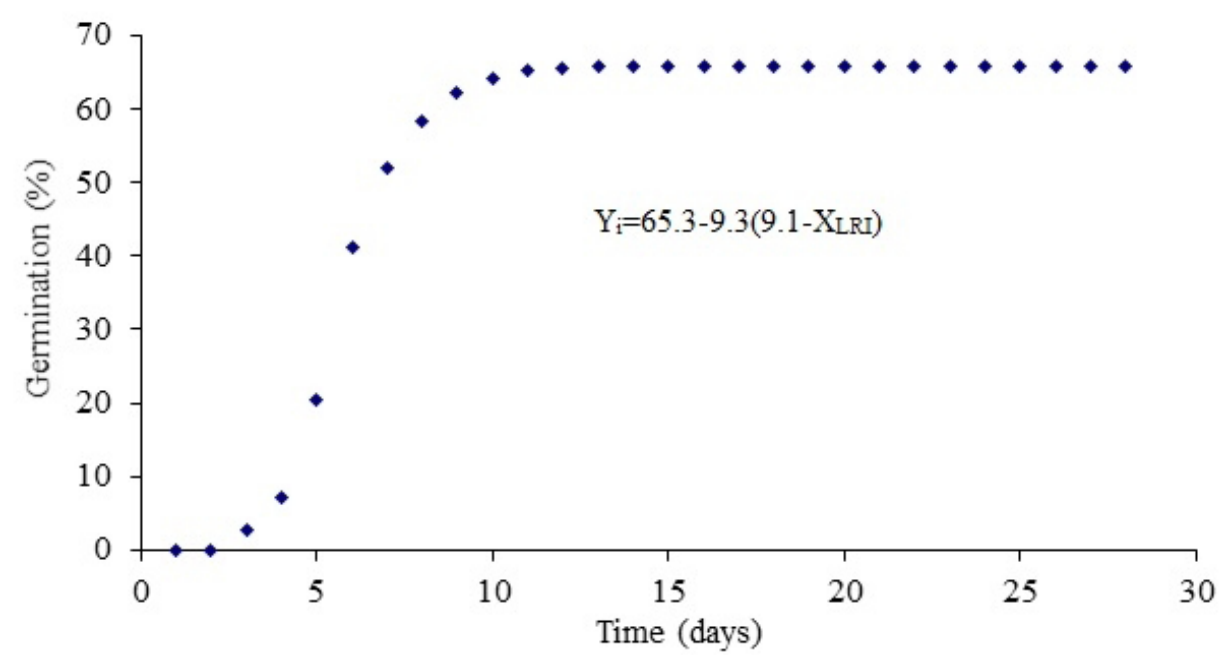

Figure 5: Germination percentage point of $B$. decumbens seeds germinating in a substrate moistened with a $\mathrm{KNO}_{3}$ solution and at alternating temperatures of $20-35^{\circ} \mathrm{C}$.

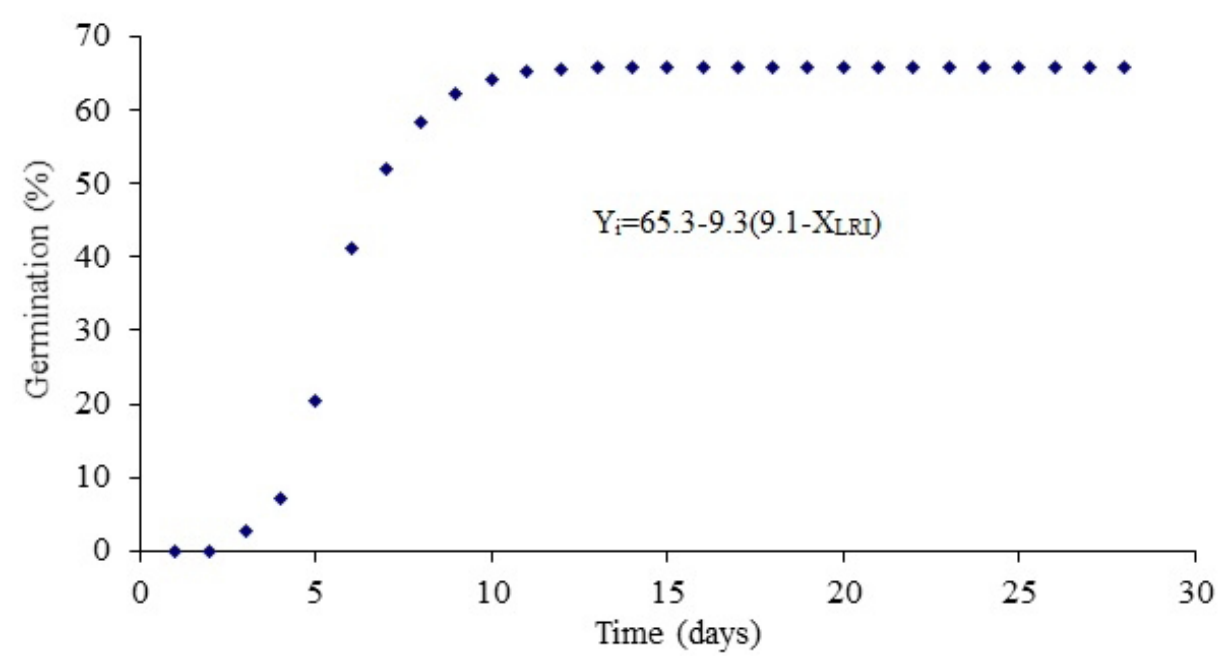

Figure 6: Germination percentage point of $B$. decumbens seeds scarified with $\mathrm{H} 2 \mathrm{SO} 4$ and at alternating temperatures of $15-35^{\circ} \mathrm{C}$. 


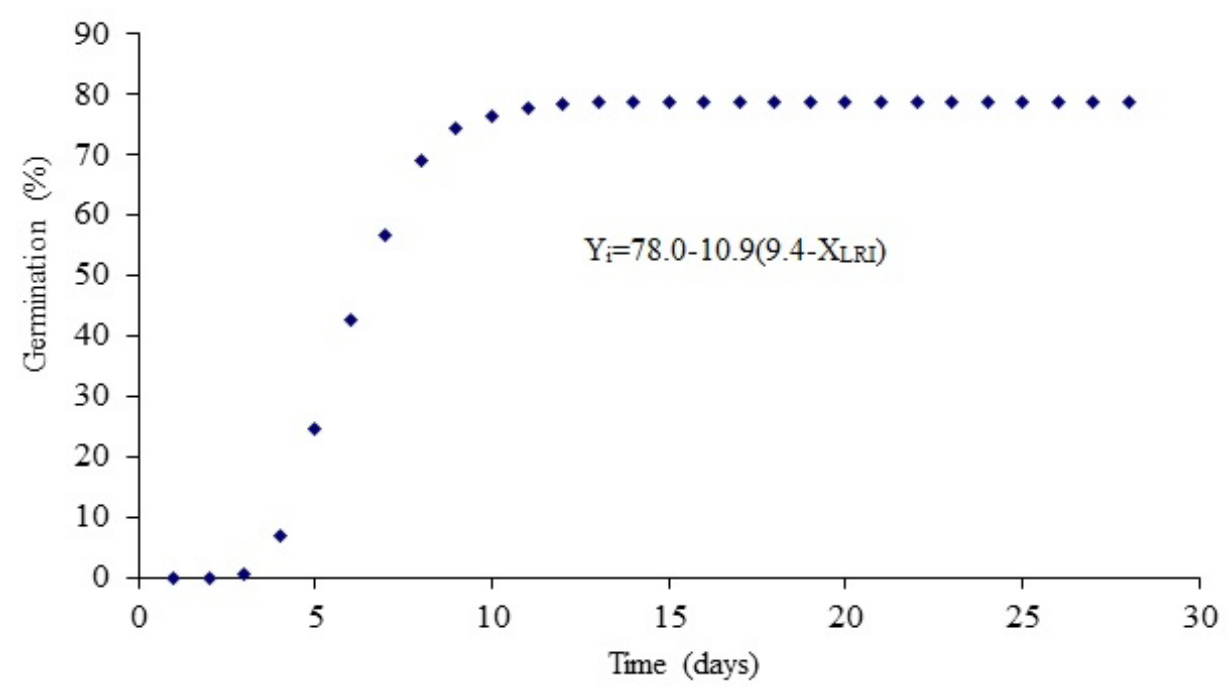

Figure 7: Germination percentage point of $B$. decumbens seeds scarified with $\mathrm{H}_{2} \mathrm{SO}_{4}$ and at alternating temperatures of $20-35^{\circ} \mathrm{C}$.

\section{CONCLUSION}

The standard germination test of $B$. decumbens seeds may be evaluated 12 days after the sowing of the seeds if carried out at the alternating temperatures of $20-35^{\circ} \mathrm{C}$ without the application of any dormancy breaking treatment.

\section{REFERENCES}

BRASIL. Instrução Normativa $n^{\circ} 30$, de 21 de maio de 2008. Normas e padrões para produção e comercialização de sementes de espécies forrageiras de clima tropical. Diário Oficial da União, Brasília, DF, 23 de maio. Anexo III. 2008.

BRASIL. Ministério da Agricultura, do Abastecimento e da Reforma Agrária. Secretaria Nacional de Defesa Agropecuária. Regras para análise de sementes. Brasília, 2009. 399p.

CARVALHO, N.M.; NAKAGAWA, J. Sementes: ciência, tecnologia e produção. Jaboticabal: FUNEP, 2012. 590p.

DIAS, M.C.L.L.; ALVES S.J. Teste de tetrazólio em sementes de Panicum maximum e Brachiaria brizantha. Londrina: IAPAR, 2001. 11p.

. Avaliação da viabilidade de sementes de Brachiaria brizantha (Hochst. ex A. Rich) stapf pelo teste de tetrazólio. Revista Brasileira de Sementes. 30(3):145-151, 2008

GASPAR-OLIVEIRA, C.M. et al. Duração do teste de germinação de Brachiaria brizantha cv. Marandu (Hochst. ex A. Rich.) Stapf. Revista Brasileira de Sementes. 30(3):30-38, 2008.

INTERNATIONAL SEED TESTING ASSOCIATION - ISTA. The Germination Test. In: International Rules for Seed Testing. Bassesrdorf: ISTA, 2009. 29p.

MARCOS-FILHO, J. Teste de envelhecimento acelerado. In: KRZYZANOWSKI, F.C.; VIEIRA, R.D.; FRANÇA NETO, J.B. (Eds.). Vigor de sementes: conceitos e testes, Londrina: ABRATES, 1999.

MARCOS-FILHO, J. Fisiologia de sementes de plantas cultivadas. Piracicaba: Fealq, 2005. 495p.

MAROUSKY, F.J.; WEST, S.H. Germination on Bahia grass in response to temperature and scarification. Journal of the American Society of Horticultural Sciences. 113(6):845-849, 1988.

MARTINS, C.C.; SILVA, W.R. Superação da dormência de sementes de capim colonião. Planta Daninha. 16:77-84, 1998. 
MASCHIETTO, R.W.; NOVEMBRE, A.D.L.C.; SILVA, W.R. Métodos de colheita e qualidade de sementes de capim colonião cultivar Mombaça.

Bragantia. 62(2):291-296, 2003.

NOVEMBRE, A.D.L.C.; CHAMMA, H.M.C.P.; GOMES, R.B.R. Viabilidade das sementes de braquiária pelo teste de tetrazólio. Revista Brasileira de Sementes. 28:147-151, 2006.

OLIVEIRA, P.R.P.; MASTROCOLA, M.A. Brachiaria humidicola (Rendle) Schweickerdt: viabilidade de suas sementes. Boletim de Indústria Animal. 40(1):49-53, 1983.

PORTZ, L.; DIAS, C.T.S.; CYRINO, J.E.P. Regressão segmentada como modelo na determinação de exigências nutricionais de peixes. Scientia Agrícola. 57(4):1-14, 2000.

QUADROS, D.G. et al. Componentes da produção e qualidade de sementes dos cultivares marandu e xaraés de Brachiaria brizantha (Hochst. ex A. Rich.) Stapf colhidas por varredura manual ou mecanizada. Semina: Ciências Agrárias. 33:20192028, 2012.
SOUZA, F.H.D. Produção de sementes de gramíneas forrageiras tropicais. São Carlos: Embrapa Pecuária Sudeste, 2001, 43p (Documento ${ }^{\circ}$ 30).

TOLEDO, F.F.; CHAMMA, H.M.C.P.; NOVEMBRE, A.D.L.C. Germinação de sementes de Panicum maximum Jacq. pré-tratadas com ácido sulfúrico. Scientia Agrícola. 52(1):20-24, 1995.

TOMAZ, C.A. et al. Duração do teste de germinação do capim-tanzânia. Revista Brasileira de Sementes. 32(4):80-87, 2010.

USBERTI, R.; MARTINS, L. Sulphuric acid scarification effects on Brachiaria brizantha, $B$. humidicola and Panicum maximum seed dormancy release. Revista Brasileira de Sementes. 29(2):143147, 2007.

VERSZIGNASSI, J.R. A pesquisa em sementes de espécies forrageiras de clima tropical no Brasil. Informativo ABRATES. 23:36-37, 2013.

ZANUZO, M.R.; MULLER, D.; MIRANDA, D.M. Análise de sementes de capim braquiária (Brachiaria brizantha $\mathrm{cv}$. Marandú) em diferentes épocas de florescimento. UNICiências.14(2):187-197, 2010. 